\title{
MENTAL HEALTHCARE FOR REFUgEES
}

\section{ATENCIÓN EN SALUD MENTAL PARA REFUGIADOS}

\section{Julio TORALES ${ }^{1}$, Israel GONZÁLEZ², Iván BARRIOS³ ${ }^{3}$ João CASTALDELLI-MAIA4, Margarita SA- MUDIO $^{5}$, Antonio VENTRIGLIO ${ }^{6}$.}

${ }^{1}$ Researcher and Professor of Psychiatry and Medical Psychology, School of Medical Sciences, National University of Asunción, San Lorenzo - Paraguay.

${ }^{2}$ Resident physician of Psychiatry, School of Medical Sciences, National University of Asunción, San Lorenzo - Paraguay.

${ }^{3}$ Teaching assistant, Research Methodology Department, School of Medical Sciences, National University of Asunción, San Lorenzo - Paraguay.

${ }^{4}$ Researcher and Professor, Department of Psychiatry, School of Medicine, University of São Paulo, São Paulo - Brazil.

${ }^{5}$ Researcher, Institute of Research in Health Sciences, National University of Asunción, San Lorenzo Paraguay.

${ }^{6}$ Researcher, Department of Clinical and Experimental Medicine, University of Foggia, Foggia - Italy.

How to cite this article: Torales J, González I, Barrios I, Castaldelli-Maia J, Samudio M, Ventriglio A. Mental healthcare for refugees. Medicina Clínica y Social. 2017;1(3):209-216.

\section{ABSTRACT}

The aim of this paper is to highlight some of the difficulties that mental health providers face when trying to provide the best standard of mental healthcare to refugees, especially in countries where the political environment is skeptic of, or even hostile to, creating programs specifically designed to improve the standard of living of this population. We also focus briefly on the dichotomy between the need to do research in this population in order to obtain data that will help us offer the best care possible to them, and the peril of undermining their autonomy by subjecting them to studies they might have otherwise refused to be part of, if they were in a less precarious position. Throughout the article, we offer practical advice that mental healthcare providers can follow to ensure that they are offering the best possible care to their patients while remaining respectful of their rights.

Keywords: Mental health providers; Mental healthcare; Refugees.

\section{RESUMEN}

El objetivo de este artículo es destacar algunas de las dificultades que enfrentan los proveedores de servicios de salud mental para tratar de proporcionar el mejor nivel de atención en salud mental a los refugiados, especialmente en países donde el entorno político es escéptico o incluso hostil, a la creación de programas específicamente diseñados para mejorar el nivel de vida de esta población. También nos enfocamos brevemente en la dicotomía entre la necesidad de investigar en esta población para obtener datos que nos ayuden a ofrecerles la mejor atención posible y el peligro de socavar su autonomía al someterlos a estudios que de lo contrario podrían haber rechazado, si es que estaban en una posición menos precaria. A lo largo del artículo, ofrecemos consejos prácticos que los proveedores de servicios de salud mental pueden seguir para garantizar que brindan la mejor atención posible a sus pacientes sin dejar de respetar sus derechos.

Palabras clave: Prestadores de salud mental; Atención en salud mental; Refugiados. 


\section{INTRODUCTION}

The United Nations Refugee Agency provides stunning statistics about the number of refugees around the world. The global refugee population is the highest on record. According to the data displayed in their website, there are 65.6 million forcibly displaced people worldwide, 22.5 million of these people are refugees (1). Refugees are defined by the United Nations High Commissioner for Refugees (UNHCR) as those "... who are outside their country of nationality or habitual residence and unable to return there owing to serious and indiscriminate threats to life, physical integrity or freedom resulting from generalized violence or events seriously disturbing public order" (2). 84\% of the refugees, about 14.5 million people, are being hosted in developing regions. More than half of them come from Syrian Arab Republic, Afghanistan, and South Sudan. Turkey is the largest host of refugees worldwide, with 2.9 million people, followed by Pakistan, with 1.4 million, and Lebanon, with 1 million. Europe hosts $17 \%$ of this population, and the Americas $16 \%$ (1).

Refugees, as all people, are entitled to the health protections afforded in the article 25 of the Universal Declaration of Human Rights (3), and in the article 12 of the International Covenant on Economic, Social and Cultural Rights (ICESR) (4).

Ensuring refugees attain the "highest attainable standard of physical and mental health" proposed by the ICESR constitutes an important strain on the healthcare infrastructure of the hosting countries. Some of them have poorly structured systems and not enough economic resources to withstand the influx of hundreds of thousands of migrants to their hospitals and clinics. On the other hand, some countries, such as Lebanon, have used this situation as an opportunity to learn and improve public healthcare services by using international donations to fund computerized health databases, purchase much needed equipment and hiring more doctors (5). Suggesting solutions for these systemic problems is outside of the scope of this paper. Nevertheless, nations, especially those in the vicinity of areas of conflict, should use all the information and resources available to make necessary changes to their healthcare infrastructure for the arrival of large groups of migrants, since providing a quick and effective response to these situations can be extremely complex, costly and socially disruptive if measures to prepare for the influx of these people are not taken in advance.

The aim of this paper is to highlight some of the difficulties that mental health providers face when trying to provide the best standard of mental healthcare to refugees, especially in countries where the political environment is skeptic of, or even hostile to, creating programs specifically designed to improve the standard of living of this population. We also focus briefly on the dichotomy between the need to do research in this population in order to obtain data that will help us offer the best care possible to them, and the peril of undermining their autonomy by subjecting them to studies they might have otherwise refused to be part of, if they were in a less precarious position. Throughout the article, we offer practical advice that mental healthcare providers can follow to ensure that they are offering the best possible care to their patients while remaining respectful of their rights. 


\section{PROVIDING THE HIGHEST ATTAINABLE STANDARD OF MENTAL HEALTHCARE TO REFUGEES}

The refugee population is at risk for many health-related issues. A meta-analysis examined the association between predisplacement and postdisplacement conditions, and the consequent mental health status of the refugees. The associations with postdisplacement conditions were predictable: materially secure conditions, measured by economic opportunities and permanent accommodation were associated with better mental health, these results indicated that psychiatric disorders such as PTSD and depression are not inexorable results of the trauma of their situation, but that other factors may influence the development of these disorders. On the other hand, the association between predisplacement conditions and mental health run somewhat against the predicted outcomes: higher level of education and socioeconomic status were thought to be protective factors against mental disorders, instead, refugees with these characteristics had worse outcomes in the meta-analysis, one possible interpretation is that refugees with these predisplacement conditions suffer a larger loss, hence becoming more predisposed to mental health issues (6).

Studies show that discriminatory practices in many regions discourage ethnic minorities from using healthcare services. They are also less likely to receive the best standard of care once they obtain access to the healthcare system (7). Immigrants in general show lower rates of utilization of mental healthcare services, likely due to cultural and linguistic barriers to care (8). When immigrants face mental health issues, they usually turn first to family, friends, or religious groups (9).

A qualitative study in Montreal tried to explain why migrants are unwilling to use mental health services, they found that perceived excessive proneness of doctors to install pharmacotherapies, a dismissive attitude from physicians, and a strong belief in nonmedical interventions were the main factors leading migrants away from mental health services (10).

Establishing a meaningful relationship with refugee patients require making an effort to understand the history of the trauma that they have suffered and its symptoms (11). Despite recommendations that physicians take a complete history of the trauma paying special attention to the psychosocial aspect, loss of friends and family members, and traumatic disability (12), physicians often remain unaware of the refugee's trauma histories (13), and are therefore unable to detect the mental health issues that may be associated to them. Some of them may be reluctant to start conversations with their healthcare providers due to a perception that cultural norms expect them to be submissive to their physicians or due to a lack of knowledge about the possible repercussions of the trauma in their mental health (14).

Posttraumatic stress disorder (PTSD) is usually considered to be the main mental health outcome of the trauma associated with being forcibly displace from one's country, but an umbrella review of thirteen meta-analyses found that major depression and anxiety could be just as prevalent in this population, affecting up to one third of the refugees and asylum seekers in certain regions (15). Total number of trauma and exposure to torture are good predictors of both PTSD and major depression (16). An often overlooked fact is that psychotic disorders, including schizophrenia, may be more frequent in refugees compared to other immigrants and the general population $(17,18)$. 
The Center for Disease Control in the United States (CDC), the World Health Organization (WHO), and many other national institutions encourage routine mental health screening during the domestic medical examination for newly arrived refugees, since this is their first interaction with the host's healthcare system $(16,19,20)$.

The following components of the mental health screening for refugees are suggested by the CDC (Table 1) (21).

\section{TABLE 1. MENTAL HEALTH SCREENING FOR REFUGEES}

\begin{tabular}{|c|c|}
\hline $\begin{array}{l}\text { Review of records } \\
\text { from oversea }\end{array}$ & $\begin{array}{l}\text { This may not be technically feasible, but a reasonable attempt should be } \\
\text { made to obtain them. }\end{array}$ \\
\hline $\begin{array}{l}\text { History and physical exami- } \\
\text { nation related to mental } \\
\text { health }\end{array}$ & $\begin{array}{l}\text { Paying special attention to signs of abuse and unexplained somatic symptoms } \\
\text { that could be related to psychological distress. }\end{array}$ \\
\hline $\begin{array}{l}\text { Mental status } \\
\text { examination }\end{array}$ & $\begin{array}{l}\text { In the form of a semi structured interview, physicians should look for signs of } \\
\text { psychotic disorders assess suicidality. }\end{array}$ \\
\hline $\begin{array}{c}\text { Screening for } \\
\text { depression and PTSD }\end{array}$ & $\begin{array}{l}\text { Although they encourage the use of standardized instruments such as the } \\
\text { PRIME-MD PHQ- } 9 \text { for depression, and the PCL-C- } 17 \text { or the Harvard Trauma } \\
\text { Questionnaire checklist for PTSD, they also emphasize that diagnoses should } \\
\text { not be made on the sole criteria of these instruments, and that individuals } \\
\text { whose scores suggest the presence of a psychiatric disorder should be re- } \\
\text { ferred to a professional healthcare provider for a more thorough evaluation. }\end{array}$ \\
\hline $\begin{array}{l}\text { Referral for refugees con- } \\
\text { sidered at significant risk }\end{array}$ & $\begin{array}{l}\text { Physicians should reassure them by clearly explaining what they can expect } \\
\text { in their visit to the specialist. }\end{array}$ \\
\hline
\end{tabular}

In following the aforementioned recommendations, mental healthcare providers must not overlook the importance of discussing the issues that motivated the migration, since they can help the physician understand the stresses that the refugee faced in the country of origin and in the route to the host country. Many refugees suffered the loss of family members, personal health and financial security. A great number of them have experienced famine, torture, and rape. The UpToDate database recommends limiting the initial screening to questions to identify suicidality and sever psychiatric disorders, leaving a more thorough mental health examination for a next interview when the physician has already established a good rapport (22). Physicians must evaluate these situations and tailor the treatment options offered to the patient to their suffering.

When a psychiatric disorder is diagnosed in these patients, the standard of care should be provided. While some clinical studies show differences in the doses needed or the adverse effect profiles in individuals from different ethnicities (23-25), in clinical practice, the pharmacologic approach does not differ greatly from what is used in the general population (26).

In order to achieve adherence to treatment in this population, physicians must assess the expectations of the patients about the drugs and their attitude towards them, ask about use of alternative or herbal medicines in a non-judgmental way, evaluate use of substances such as tobacco and alcohol with consideration of their cultural norms, and explain the side effects of 
the medications in advance while monitoring them throughout the duration of the treatment (27).

Psychotherapies are the mainstay of treatment in PTSD and a first-line alternative in major depression and anxiety disorders (28). Standard cognitive behavioral therapy or psychodynamic approaches are usually the standard of care, but it can be hard to find enough trained providers to support an important influx of people to a host country.

Some therapies are being devised to directly address the needs of refugees (29). Brief, structured, and standardized psychotherapy packages that draw on trauma focused CBT have been developed and applied successfully to refugees over the last decades, these programs can be easily adapted to new cultures, and are designed so that workers can be rapidly trained to use them, instead of requiring years of training (30). Psychosocial interventions focus on the wellbeing of the population as a whole, studies have found that these interventions effectively increase self-confidence, decrease isolation, and increase access to mental healthcare services $(31,32)$.

\section{ETHICS AND THE NEED FOR RESEARCH IN THE REFUGEE POPULATION}

As physicians, we are constantly looking for evidence-based solutions to the problems we face. Refugees can certainly benefit from evidence resulting in better pharmacologic treatments, more directed and available psychotherapies, better targeted social approaches, and policies supported by strong evidence and not based merely on political arguments.

In order to find these solutions, researchers face a "dual imperative" to balance their concerns about reducing suffering and their professional duty to produce research with the highest scientific standards (33). Ethical considerations should guide the research process without compromising on research design, in order to produce studies that will be actually useful for the affected groups (34).

The European Commission provides a guidance note listing the general principles to follow when research involves refugees, including treating them with care and sensitivity, being objective and transparent, avoiding ethnocentricity, safeguarding their autonomy, dignity, wellbeing, and security, respecting their values and their right to consent, and giving special protections to participants with diminished autonomy, such as unaccompanied minors. They raise the issue that traditional informed consent forms can be harmful to the refugees because they can discourage participants, jeopardize their anonymity and be difficult to translate to their language in a comprehensible style. They suggest using less formalized procedures for providing information and obtaining consent. This can be achieved by including cultural insiders in the process, working with reputable NGOs, and using oral consent with the knowledge and approval of a competent Research Ethics Committee (35).

\section{CONCLUSION}

Access to the best standard of mental healthcare, and healthcare in general, is one of the most important human right to secure for refugees, since it is essential to allow them to enjoy other human rights (36). Refugees should be screened for mental health disorders as soon as they reach the host countries, and physicians must make adjustments in their style of questioning and their treatment approaches to accommodate to this special population. 
Researchers should be encouraged to study this population in order to find the best strategies to provide care for refugees. At the same time, they should be held to a high standard not only in their research design, but in their respect for the autonomy and the dignity of this vulnerable group.

\section{CONFLICTS OF INTEREST AND FUNDING}

Conflicts of interest: none. Funding source: none.

\section{REFERENCES}

1. The United Nations Refugee Agency [Internet]. Geneva: United Nations Refugee Agency; c2017 [cited 03 Nov 2017]. UNHCR - Figures at a Glance [approx. 4 screens]. Available from: http://www.unhcr.org/figures-at-a-glance.html

2. The United Nations Refugee Agency [Internet]. Geneva: United Nations Refugee Agency; c2011 [cited 04 Nov 2017]. UNHCR Resettlement Handbook [approx. 21 screens]. Available from: http://www.unhcr.org/3c5e55594.html

3. The United Nations General Assembly. Universal Declaration of Human Rights. The International Journal of Human Rights 1998;2(3):84-88. https://doi.org/10.1080/13642989808406748

4. The United Nations General Assembly [Internet]. Geneva: United Nations General Assembly; c2017 [cited 04 Nov 2017]. International Covenant on Economic, Social and Cultural Rights. United Nations, Treaty Series, 999(14531), 3. [approx. 67 screens]. Available from: http://www.refworld.org/docid/3ae6b36c0.html

5. Sleiman D, Atallah D [Internet]. Geneva: United Nations Refugee Agency; c2016 [cited 04 Nov 2017]. With Syria refugee crisis, Lebanese health services improve [approx. 6 screens]. Available from: http://www.unhcr.org/news/stories/2016/9/57ce7e7d4/syria-refugee-crisislebanese-health-services-improve.html

6. Porter M, Haslam N. Predisplacement and Postdisplacement Factors Associated With Mental Health of Refugees and Internally Displaced Persons. JAMA 2005;294(5):602612. https://doi.org/10.1001/jama.294.5.602

7. Burnes Bolton L, Giger JN, Georges CA. Structural and racial barriers to health care. Annu Rev Nurs Res. 2004;22:39-58. URL.

8. Kirmayer LJ, Weinfeld M, Burgos G, du Fort GG, Lasry J-C, Young A. Use of health care services for psychological distress by immigrants in an urban multicultural milieu. Canadian Journal of Psychiatry 2007;52(5):295-304. https://doi.org/10.1177/070674370705200504

9. Derr AS. Mental Health Service Use Among Immigrants in the United States: A Systematic Review. Psychiatric Services 2016;67(3):265-274. https://doi.org/10.1176/appi.ps.201500004

10. Whitley R, Kirmayer LJ, Groleau D. Understanding Immigrants' Reluctance to Use Mental Health Services: A Qualitative Study from Montreal. The Canadian Journal of Psychiatry 2006;51(4):205-209. https://doi.org/10.1177/070674370605100401

11. Crosby SS. Primary care management of non-English-speaking refugees who have experienced trauma: a clinical review. JAMA 2013;310(5):519-528. https://doi.org/10.1001/jama.2013.8788 
12. Mollica RF. Assessment of Trauma in Primary Care. JAMA 2001;285(9):1213. https://doi.org/10.1001/jama.285.9.1213-JMS0307-3-1

13. Eisenman DP, Keller AS, Kim G. Survivors of torture in a general medical setting: how often have patients been tortured, and how often is it missed? The Western Journal of Medicine 2000;172(5):301-304. URL.

14. Shannon $P, O^{\prime}$ Dougherty $M$, Mehta $E$. Refugees' perspectives on barriers to communication about trauma histories in primary care. Mental Health in Family Medicine 2012; 9(1):47-55. URL.

15. Turrini G, Purgato M, Ballette F, Nosè M, Ostuzzi G, Barbui C. Common mental disorders in asylum seekers and refugees: umbrella review of prevalence and intervention studies. International Journal of Mental Health Systems 2017;11:51. https://doi.org/10.1186/s13033-017-0156-0

16. Priebe S, Giacco D, El-Nagib R. Public Health Aspects of Mental Health Among Migrants and Refugees: A Review of the Evidence on Mental Health Care for Refugees, Asylum Seekers and Irregular Migrants in the WHO European Region. Copenhagen: WHO Regional Office for Europe; 2016. URL.

17. Dapunt J, Kluge $U$, Heinz A. Risk of psychosis in refugees: a literature review. Translational Psychiatry 2017;7(6):e1149. https://doi.org/10.1038/tp.2017.119

18. Hollander AC, Dal H, Lewis G, Magnusson C, Kirkbride JB, Dalman C. Refugee migration and risk of schizophrenia and other non-affective psychoses: cohort study of 1.3 million people in Sweden. BMJ. 2016;352:i1030. https://doi.org/10.1136/bmj.i1030

19. Pottie K, Greenaway C, Feightner J, Welch V, Swinkels H, Rashid M, et al. Evidencebased clinical guidelines for immigrants and refugees. Canadian Medical Association Journal 2011;183(12):E824-E925. https://doi.org/10.1503/cmaj.090313

20. U.S. Department of Health and Human Services [Internet]. Washington DC: U.S. Department of Health and Human Services; c2012 [cited 05 Nov 2017]. Summary Checklist for the Domestic Medical Examination for Newly Arriving Refugees [approx. 8 screens]. Available from: http://www.cdc.gov/immigrantrefugeehealth/guidelines/domestic/checklist.html

21. U.S. Department of Health and Human Services, Centers for Disease Control and Prevention, National Center for Emerging and Zoonotic Infectious Diseases, Division of Global Migration and Quarantine [Internet]. Washington DC: U.S. Department of Health and Human Services, Centers for Disease Control and Prevention, National Center for Emerging and Zoonotic Infectious Diseases, Division of Global Migration and Quarantine; c2015 [cited 05 Nov 2017]. Guidelines for Mental Health Screening During the Domestic Medical Examination for Newly Arrived Refugees (Vol. 1) [approx. 7 screens]. Available from: https://www.cdc.gov/immigrantrefugeehealth/guidelines/domestic/mental-healthscreening-guidelines.html\#two

22. Walker $P$, Barnett $E$, Stauffer $W$. Healthcare for adult immigrants and refugees. Baron E, ed. UpToDate. Waltham, MA: UpToDate Inc. URL.

23. Lin KM, Poland RE, Nuccio I, Matsuda K, Hathuc N, Su TP, et al. A longitudinal assessment of haloperidol doses and serum concentrations in Asian and Caucasian schizophrenic patients. American Journal of Psychiatry 1989;146(10):1307-1311. https://doi.org/10.1176/ajp.146.10.1307

24. Marcos LR, Cancro R. Pharmacotherapy of Hispanic depressed patients: clinical observations. Am J Psychother 1982;36:505-512. 
25. Strickland TL, Lin KM, Fu P, Anderson D, Zheng Y. Comparison of lithium ratio between African-American and Caucasian bipolar patients. Biological Psychiatry 1995;37(5):325-330. https://doi.org/10.1016/0006-3223(94)00133-N

26. Silove $D$, Ventevogel $P$, Rees $S$. The contemporary refugee crisis: an overview of mental health challenges. World Psychiatry 2017;16(2):130-139. https://doi.org/10.1002/wps.20438

27. Bhugra D, Gupta S, Bhui K, Craig T, Dogra N, Ingleby JD, et al. WPA guidance on mental health and mental health care in migrants. World Psychiatry 2011;10(1):2-10. https://doi.org/10.1176/appi.focus.130406

28. Torales J, Arce A, Zacarías M, Girala N, Moreno M, Szwako A, et al. La Guía TAZ de Psicofarmacología Clínica. 1a ed. Asunción: EFACIM; 2014. URL.

29. Buhmann C, Andersen I, Mortensen EL, Ryberg J, Nordentoft M, Ekstrøm M. Cognitive behavioral psychotherapeutic treatment at a psychiatric trauma clinic for refugees: description and evaluation. Torture. 2015;25(1):17-32. URL.

30. Hinton DE, Pich V, Hofmann SG, Otto MW. Acceptance and Mindfulness Techniques as Applied to Refugee and Ethnic Minority Populations With PTSD: Examples From "Culturally Adapted CBT". Cognitive and Behavioral Practice 2013;20(1):33-46. https://doi.org/10.1016/j.cbpra.2011.09.001

31. Van Ee E, Mooren T, Kleber R. Broken mirrors: Shattered relationships within refugee families. In: Pat-Horenczyk R, Brom D, Vogel JM, eds. Helping Children Cope with Trauma: Individual, Family and Community Perspectives. London: Routledge; 2014: 146-162. https://doi.org/10.4324/9781315857756

32. Weine S, Kulauzovic Y, Klebic A, Besic S, Mujagic A, Muzurovic J, et al. Evaluating A Multiple-Family Group Access Intervention for Refugees with PTSD. Journal of Marital and Family Therapy 2008;34(2):149-164. https://doi.org/10.1111/j.17520606.2008.00061.x

33. Jacobsen K, Landau LB. The Dual Imperative in Refugee Research: Some Methodological and Ethical Considerations in Social Science Research on Forced Migration. Disasters 2003;27(3):185-206. https://doi.org/10.1111/1467-7717.00228

34. Birman D. Ethical Issues in Research With Immigrants and Refugees. In: Trimble JE, Fisher CB, eds. The Handbook of Ethical Research with Ethnocultural Populations and Communities. California: Sage Publications; 2005: 155-177. URL.

35. European Commission [Internet]. Brussels: European Commision; c2016 [cited 06 Nov 2017]. Guidance note - Research on refugees, asylum seekers \& migrants [approx. 5 screens]. Available from: http://ec.europa.eu/research/participants/data/ref/h2020/other/hi/guide research-refugees-migrants en.pdf

36. Torales J, Villalba-Arias J, Ruiz-Díaz C, Chávez E, Riego V. The right to health in Paraguay. International Review of Psychiatry 2014;26(4):524-529. https://doi.org/10.3109/09540261.2014.926866 